Marta DOŁĘGA

Instytut Paliw i Energii Odnawialnej Warszawa

Krzysztof BIERNAT

IEiB WFCh UKSW Warszawa

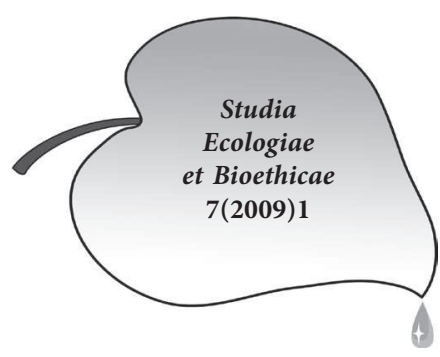

\title{
Procesy zarządzania ryzykiem ekologicznym
}

\section{Wprowadzenie}

Wystąpienie ryzyka można określić jako ilościową ocenę stopnia możliwości nastąpienia danej szkody losowej lub nieszczęśliwego wypadku. W zależności od tego, w jakich obszarach ryzyko występuje, straty można ująć finansowo, czasowo (postęp ekonomiczny, technologiczny i cywilizacyjny, itp.), osobowo, społecznie lub przyrodniczo. Rozróżniane są także metody liczenia prawdopodobieństwa wystąpienia szkody (np. probalistyczne, estymacyjne).

Ryzyko jako zdarzenie losowe może być zarówno pozytywne (w przypadku wystąpienia korzyści) jak i negatywne, gdy w rezultacie wystąpi wynik inny niż oczekiwany (strata, szkoda majątkowa, utrata życia, zdrowia itd.). Jego zrealizowanie jest możliwe, ale nie konieczne, nieprzewidywalne albo prawdopodobne, niezależne od jednostki nim dotkniętej lub też występuje za sprawą złego zanalizowania i podjęcia ryzyka przez jednostkę.

\section{Ryzyko ekologiczne}

Ryzykiem ekologicznym jest prawdopodobieństwo nastąpienia zdarzenia, które spowoduje degradację środowiska naturalnego i związane z tym skutki. Szczególny rodzaj zagrożeń występujących w środowisku to klęski o charakterze naturalnym, powodzie, huragany, trzęsienia ziemi, katastrofy i wypadki związane z technologiami i wytworami (uwalnianie się niebezpiecznych substancji chemicznych, wybuchy, katastrofy komunikacyjne), charakteryzujące się niepowtarzalnością, losowością, wieloprzyczynowością i różnorodnością bezpośrednich skutków. Mogą one powodować zagrożenie zdrowia i życia ludzi, degradację środowiska czy też poważne straty gospodarcze.

Sprawny proces zarządzania przeciw wystąpieniu zagrożenia ekologicznego polega, więc na ochronie ludzi i zasobów przyrody przed zagrożeniami związanymi 
z zanieczyszczaniem wody, powietrza, gleby, a także innych komponentów środowiska, w którym została naruszona równowaga. Szkodą w przypadku wystapienia zagrożenia są negatywne skutki środowiskowe spowodowane nadmiernym zanieczyszczeniem komponentów środowiska lub zmianami w ekosystemach znajdujących się w zasięgu oddziaływania sprawcy. Czynnikami wpływającymi na znaczenie szkody ekologicznej jest jej wielkość, rozległość, czas trwania oraz charakter szkodliwego działania zanieczyszczenia.

Od oczekiwanej intensywności działania zdarzenia losowego zależy wielkość ryzyka. Ryzyko jest tu więc niewiadomą w tym znaczeniu, że jest to pewna wielkość z przedziału $(0 ; 1)$.

W przypadku niebezpieczeństw ekologicznych, ryzyko to także potencjalna zmienność zdarzeń, których skutków nie da się precyzyjnie przewidzieć i w którego wyniku, zagrożeniu może być poddana pewna liczba ludzi lub człowiek jako jednostka. Poziom ryzyka, w postaci matrycy jakościowej analizy ryzyka, przedstawiono w tabeli 1.

Tabela 1. Matryca jakościowej analizy ryzyka - poziom ryzyka

\begin{tabular}{|l|l|l|l|l|l|}
\hline \multirow{2}{*}{$\begin{array}{c}\text { Możliwość } \\
\text { wystąpienia } \\
\text { zdarzenia }\end{array}$} & \multicolumn{5}{|c|}{ Skutki } \\
\cline { 3 - 6 } & Nieistotne & Małe & Średnie & Duże & Katastrofalne \\
\hline Frawie pewna & wysoki & wysoki & ekstremalny & ekstremalny & ekstremalny \\
\hline Frawdopodobna & średni & wysoki & wy soki & ekstremalny & ekstremalny \\
\hline Możliwa & niski & średni & wy soki & ekstremalny & ekstremalny \\
\hline Niemożliwa & niski & niski & średni & wysoki & ekstremalny \\
\hline Rzadka & niski & niski & średni & wysoki & wysoki \\
\hline
\end{tabular}

\section{Główne czynniki ryzyka}

Najważniejszymi czynnikami ryzyka jest niebezpieczeństwo i hazard. Niebezpieczeństwo określane jest jako powód szkody. Występuje stopniowo, jako serie niezależnych zdarzeń prowadzących do wypadku. Jako pierwsze pojawiają się zagrożenia (potencjalne niebezpieczeństwo), które poprzez zrealizowanie się warunkują dane skutki. Rozpoczyna się wówczas proces szacowania wielkości szkody i eliminowania zdarzenia losowego.

Hazard jest główną okolicznością wpływającą na akt realizacji niebezpieczeństwa. Może on występować jako zespół właściwości fizycznych, od których 
uzależnione jest wystąpienie niebezpieczeństwa. Może wynikać z nieuczciwości lub innych defektów jednostki, które zwiększają częstość i rozmiar szkody w celu uzyskania korzyści materialnych jak również z beztroskiej obojętności względem szkód (obniżeniem staranności, niedbalstwem lub obojętnością wobec zagrożenia).

\section{Proces zarządzania ryzykiem}

Proces zarządzania ryzykiem polega na identyfikacji, ocenie, kontrolowaniu oraz finansowaniu zagrożenia i powstałej szkody. Procedura ta musi być jednak poprzedzona analizą możliwości wystąpienia ryzyka. Analiza ryzyka zazwyczaj zawiera trzy elementy: zbiór informacji, rozpoznanie zagrożeń i zbiór danych niezbędnych do szacowania ryzyka. Polega na rozpoznaniu, zrozumieniu natury ryzyka, poznaniu w jaki sposób powstają ryzyka i w jaki sposób wpływają na zaistnienie strat lub korzyści. Analiza pozwala na zorientowanie się, w jaki sposób powstają straty i w jaki sposób konkretne następstwo zdarzeń przekształca zagrożenie $\mathrm{w}$ stratę. Ocenie poddawane są zidentyfikowane potencjalne zagrożenia, rodzaj ryzyka występujący przy zidentyfikowanych zagrożeniach lub ich kombinacjach, stopień narażenia stref pośrednich, opis skutków oddziaływania zagrożenia, ich wpływu i czasu odczuwania oraz kosztów. Całokształt procesu analizy ryzyka przedstawiono $\mathrm{w}$ formie algorytmu, na rys. 1.

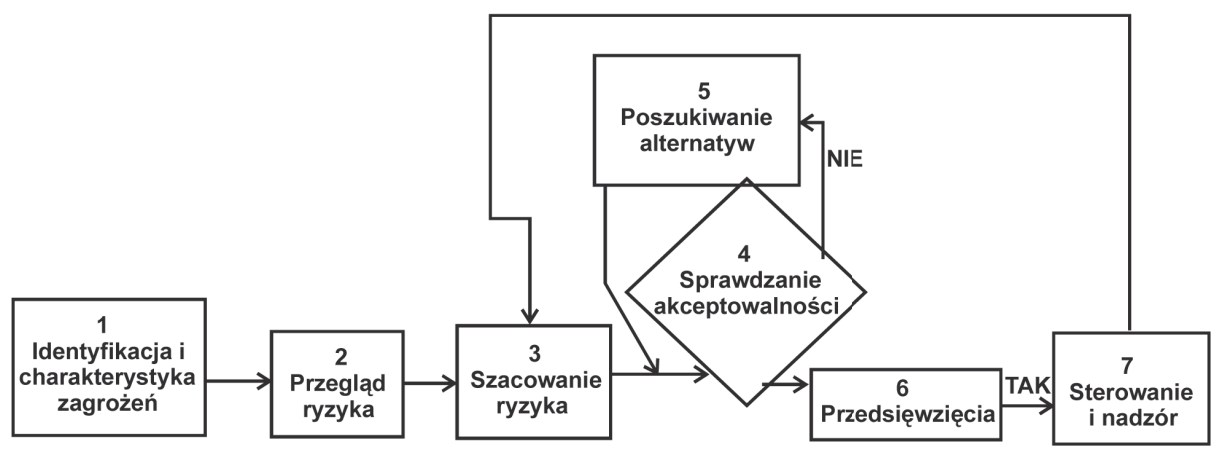

Rys. 1. Proces analizy ryzyka

W przypadku ryzyka ekologicznego, analizą mogą być objęte przedsięwzięcia specyficzne dla określonych procesów technologicznych, instalacji, czynności operacyjnych, procesów chemicznych (ze względu na zagrożenie pożarem lub wybuchem), systemów bezpieczeństwa, działań prewencyjnych, ewentualnych problemów produkcyjnych oraz powstałych awarii w trakcie procesów. Często odpowiednio dobrana analiza pozwala na identyfikację wzajemnie powiązanych błędów ludzkich i technicznych defektów, które prowadzą do określonych skutków. 
Dokładną analizę można przeprowadzić również poprzez identyfikację i ocenę początkowych zdarzeń, mogących prowadzić do zniszczeń, poprzez ukazanie związków, które istnieją między różnymi stadiami wypadku. Możliwe klasy skutków związanych z zagrożeniem środowiska przedstawiono w tabeli 2.

Tabela 2. Skutki związane z zagrożeniem środowiska

\begin{tabular}{|c|c|}
\hline Klasa & Charakterystyka \\
\hline A. Nieistotne & Brak zanieczyszczeń, skutki zlokalizowane. \\
\hline B. Ogyaniczone & Niewielkie zarieczyszczenia, skutki zlokalizowane. \\
\hline C. Poważne & Niewielkie zarieczyszczenie, skutki rozległe. \\
\hline D. Bardzo poważne & Duzie zarieczyszczenie, skutki zlokalizowane. \\
\hline E. Katastrofalme & Bardzo duże zanieczyszczenie, skutki rozlegke. \\
\hline
\end{tabular}

Po dokładnej analizie można rozpocząć proces zarządzania ryzykiem. Pełna procedura oparta jest na szacowaniu ryzyka wraz z jego sterowaniem, jak to przedstawiono na rys. 2. Poprzez szacowanie ryzyka rozumie się procedurę opartą na analizie, łącznie z uwzględnieniem skutków socjologicznych, ekonomicznych, środowiskowych, a także wartościowania elementów istotnych przy dokonywaniu wyborów w procesie podejmowania decyzji związanych ze zmniejszeniem ryzyka do akceptowanego społecznie poziomu. Sterowanie związane jest z podejmowaniem decyzji niezbędnych do zarządzania ryzykiem, ich wdrażaniem oraz legislacją wraz $\mathrm{z}$ okresowym badaniem efektywności tych działań. 


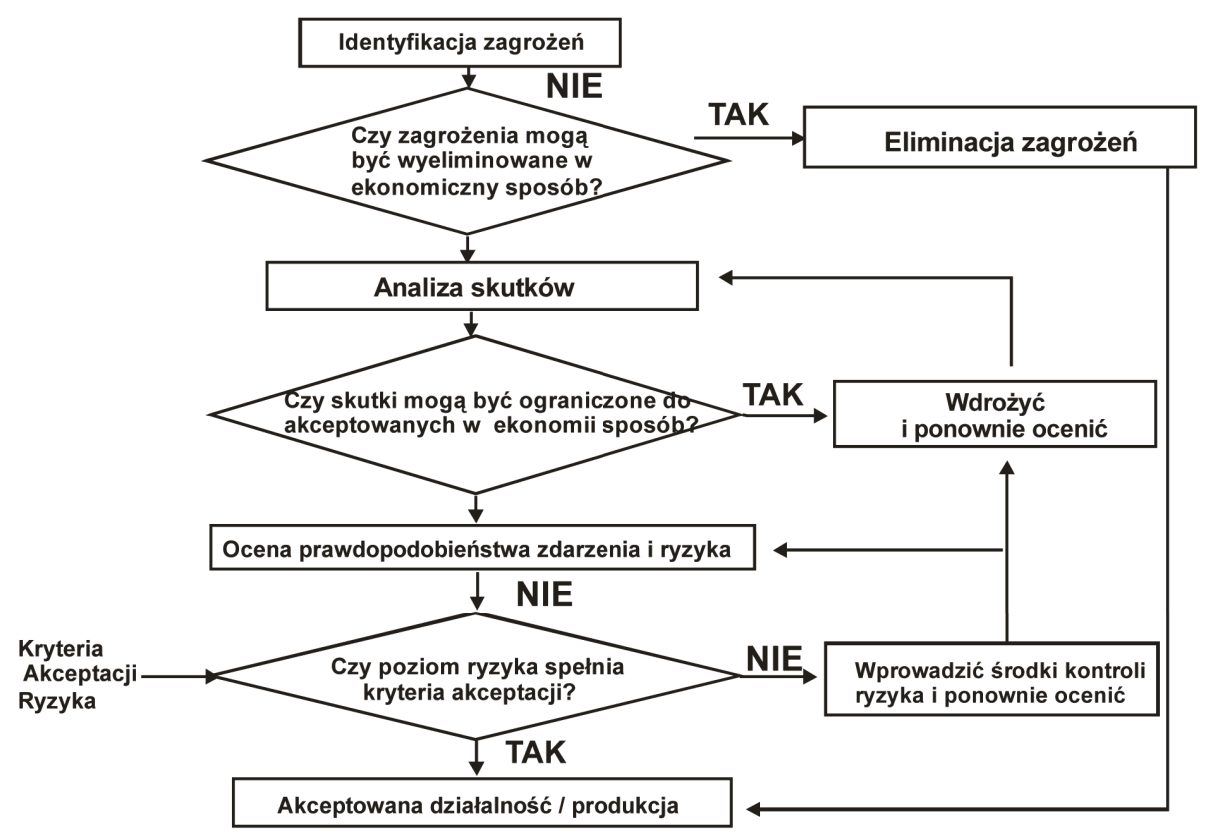

Rys. 2. Ogólna procedura szacowania ryzyka

Głównym etapem procedury zarządzania ryzykiem jest jego identyfikacja. Identyfikowane są zagrożenia jako ogół działań lub warunków, które powodują powstanie strat lub zwiększają prawdopodobieństwo ich powstania, a także potencjalne źródła zagrożeń, które mogą prowadzić do pozytywnych lub negatywnych skutków. Celem identyfikacji ryzyka jest gromadzenie informacji na temat źródeł ryzyka, zagrożeń, czynników ryzyka, niebezpieczeństwa i podatności na straty (ilość jednostek narażonych).

Czynnikami wpływającymi na ocenę ryzyka są zazwyczaj dane historyczne, czyli pewne typy zdarzeń, które już miały miejsce w przeszłości, ponieważ określone warunki i podatność sprzyjały powstawaniu niekorzystnych zdarzeń. I chociaż przestały one istnieć lub zostały istotnie zredukowane to jednak zakłada się, że podobne sytuacje nadzwyczajne mogą zaistnieć. Należy jednak pamiętać, że niedostępność danych związanych zagrożeniami, dane o nieznanej wiarygodności, jak również zbyt dużo danych na temat zagrożeń wiąże się z często występującymi trudnościami związanymi z określeniem, które z nich są odpowiednie.

Głównym problemem może być więc brak wiedzy związanej z zastosowaniem określonych metod szacowania podatności oraz brak wiedzy na temat specyficznych zagrożeń. Ważna jest również elastyczność wypracowanych procesów zarządzania ryzykiem, gdyż sztywne schematy mogą spowodować koniec procesu, 
ze względu na brak możliwości powrotu do kroku poprzedniego w przypadku, gdy sytuacja tego wymaga. Głównymi rezultatami wynikającymi z planów zarządzania ryzykiem powinno być więc poznanie i zrozumienie procesów zachodzących podczas wystąpienia niebezpieczeństwa, wiedza na temat ich wrażliwości na zmiany, efektywne pod względem kosztów środki zarządzania zagrożeniem, a także wykaz gdzie należy stosować dalsze działania/badania.

\section{Ograniczenie ryzyka wystąpienia poważnych awarii}

Poprawa bezpieczeństwa ekologicznego związanego z działalnością produkcyjną przedsiębiorstw wiąże się z identyfikacją ryzyka poprzez zidentyfikowanie obiektów stwarzających ryzyko wystąpienia poważnej awarii przemysłowej oraz okresową kontrolą instalacji mogących spowodować poważną awarię. Niezbędne jest sporządzanie raportów bezpieczeństwa, zakładowych planów zarządzania ryzykiem i planów operacyjno-ratowniczych dla obiektów niebezpiecznych, objętych wymogami prawa ochrony środowiska, jak również zapewnienie bezpieczeństwa podczas przewozu materiałów niebezpiecznych:

$\triangleright \quad$ wyznaczenie stałych tras przewozu drogowego materiałów niebezpiecznych,

$\triangleright$ zapewnienie sprawnego nadzoru nad transportem,

$\triangleright$ nałożenie na przewoźników obowiązku powiadamiania o przewozie jednostek policji i Państwowej Straży Pożarnej.

Ograniczenie ryzyka wystąpienia awarii ze skutkami dla środowiska związane jest $\mathrm{z}$ analizą możliwych przyczyn uwolnienia się substancji niebezpiecznych. Zestawienie podstawowych przyczyn przedstawiono w tabeli 3.

Tabela 3. Przyczyny awaryjnych uwolnień niebezpiecznych substancji

\begin{tabular}{|c|c|c|}
\hline $\begin{array}{l}\text { Uszkodzenia mechaniczne } \\
\text { gwałtowne lub stopniowe }\end{array}$ & $\begin{array}{l}\text { Uwolnienia procesowe } \\
\text { (upusty, zawory } \\
\text { bezpieczeństwa) }\end{array}$ & $\begin{array}{l}\text { Nieprzewidziane reakcje } \\
\text { pomiędzy substancjami } \\
\text { odwadniającymi (np. kwas } \\
\text { solny i siarczyn sodu) }\end{array}$ \\
\hline $\begin{array}{l}\text { •uderzenie, } \\
\text { •nadciśnienie, } \\
\text { •przegrzanie, } \\
\text { •kruchość materiałów (np. } \\
\text { szkła, rur z tworzyw } \\
\text { sztucznych, itp.), } \\
\text { •korozja (np. rur, } \\
\text { zbiorników), } \\
\text { •przekroczenie naprężenia } \\
\text { krytycznego, } \\
\text { •miejsca uszkodzeń } \\
\text { mechanicznych, } \\
\text { •dławikowe uszczelki } \\
\text { sprężarek, } \\
\text { •wibracje. }\end{array}$ & $\begin{array}{l}\text {-uszkodzenia systemów } \\
\text { sterowania i zabezpieczeń, } \\
\text { •stany eksploatacyjne } \\
\text { instalacji wykraczające poza } \\
\text { granice ustalone założeniami } \\
\text { projektowymi, } \\
\text { •nieprawidłowy przebieg } \\
\text { operacji napełniania i } \\
\text { rozładowywania } \\
\text { •niewłaściwe oczyszczanie } \\
\text { instalacji przed konserwacją, }\end{array}$ & $\begin{array}{l}\text {-reakcje uboczne w czasie } \\
\text { procesu, } \\
\text { •reakcje chemiczne pomiędzy } \\
\text { substancjami procesowymi } \\
\text { a niewłaściwie dobranymi } \\
\text { środkami gaśniczymi, } \\
\text { •reakcje w odstojnikach } \\
\text { ścieków. }\end{array}$ \\
\hline
\end{tabular}


Kolejnym etapem całej procedury jest pomiar ryzyka, który pozwala na określenie prawdopodobieństwa poniesienia strat lub odniesienia korzyści i oszacowanie ich wartości w zależności od częstości i intensywności występowania. Pomiar ryzyka może przyjąć formę oceny jakościowej (rodzaj i natężenie zagrożenia) oraz oceny ilościowej (liczba osób, wielkość mienia i rozmiary szkód środowiskowych). Taka całościowa ocena pozwala na rozpoczęcie kontroli nad wystąpieniem danego zagrożenia poprzez zapobieganie, ograniczanie wystąpienia ryzyka oraz działania na rzecz kontroli ryzyka. Zapobieganie jako zmniejszenie liczby strat polega również na zmianie lub modyfikacji zagrożenia oraz otoczenia, w którym istnieje zagrożenie.

Celem ograniczenia strat jest zmniejszenie ich wpływu poprzez zbadanie okoliczności zdarzenia, kontrolę jego bezpośrednich skutków lub kontrolę długookresowych konsekwencji. Jako działania kontrolne stosuje się prewencję, przygotowanie planu działania na ewentualność nieprzewidzianej katastrofy oraz przygotowanie planu przetrwania.

Dużą rolę w na tym etapie odgrywa prewencja, która ma za zadanie ograniczenie do minimum prawdopodobieństwa wystąpienia katastrofy lub awarii. Ponieważ katastrof nie można uniknąć, ani im całkowicie zapobiec, istotne znaczenie ma przewidywanie ich skutków. Jest to możliwe dzięki stosowaniu się do wcześniej przygotowanych planów ratowniczych, procedur postępowania, zapewnienia sił i środków, systemów powiadamiania i ewakuacji ludności. Jak również dzięki zapewnieniu prawidłowego postępowania poawaryjnego oraz umiejętność analizy wyciągania wniosków na przyszłość z zaistniałej sytuacji.

W przypadku zagrożeń ekologicznych niezbędne jest prowadzenie wzmocnionych działań mających na celu zwiększenie świadomości społeczeństwa, w celu uniknięcia paniki i umożliwienia prawidłowych reakcji (określonych zachowań). Kluczowe znaczenie ma także współpraca na szczeblu lokalnym, dzięki której możliwe jest przeprowadzenie sprawnego, systemu prewencji i przeciwdziałania w sytuacjach niebezpiecznych.

Końcowym etapem procesu zarządzania ryzykiem jest ogół działań na rzecz finansowania ryzyka, polegających na dostarczeniu środków na pokrycie strat i na finansowaniu innych programów, mających na celu zmniejszenie niepewności i ryzyka lub zwiększenie zakresu pozytywnych wyników.

\section{Wnioski}

Szacowanie poziomu ryzyka jest bardzo istotnym elementem w zapobieganiu zagrożeń środowiska. Analiza poziomu zagrożenia, niezależnie od konieczności stałego monitorowania, prowadzona być powinna przy wprowadzaniu nowych rozwiązań technologicznych, bądź modernizacji rozwiązań dotychczas stosowanych. Wprowadzane rozwiązania z zakresu technologii, transportu, gospodarki odpadami, zagospodarowaniem przestrzennym itp. powinny uwzględniać możli- 
wie wszystkie zagrożenia oraz przewidywać scenariusze postępowania na wypadek wystąpienia różnych zdarzeń, $\mathrm{w}$ tym zdarzeń losowych. Istotny element tego typu działań stanowi wybór podstawowych kryteriów niezbędnych do oceny właściwej opcji ograniczania ryzyka. Wybrane kryteria zostały przedstawione w tabeli 4.

Tabela 4. Wybrane kryteria niezbędne do oceny opcji ograniczania ryzyka

\begin{tabular}{|c|c|}
\hline Kryteria & Pytania \\
\hline Równośc & $\begin{array}{l}\text { Czy Ci, którzy sa odpowiedzialni za tworzenie tyzyka } \\
\text { placa za jego redukcje? Czy kossty sa uczciwe } \\
\text { podzielone w przypadku gdy przyczyna nie jest } \\
\text { czlowiek? }\end{array}$ \\
\hline Caas & $\begin{array}{l}\text { Czy uzyska sie pozytywne efekty tej opcji jeżeli } \\
\text { szybko zostanie zrealizowana? }\end{array}$ \\
\hline Frzelożenie & $\begin{array}{l}\text { Czy zastosowanie tej opcji prowadzi do dalszych } \\
\text { dziatan redukcji tyzyka podjetych przez innych? }\end{array}$ \\
\hline Kosty & $\begin{array}{l}\text { Cay opcja ta jest najbardziej efektywna lub ozy mozina } \\
\text { uzyskac te same rezultaty poprzez zastosowanie } \\
\text { tanszych sposobow? }\end{array}$ \\
\hline Efektywność adtninistracyjna & $\begin{array}{l}\text { Czy latwo jest administrować wybrana opcja czy tez } \\
\text { wytrik będa nieistotne a powodu trudności } w \\
\text { adtuinistrowaniu? }\end{array}$ \\
\hline Ciqgłość efektów & $\begin{array}{l}\text { Czy efekty wybranej opcji będa dhugottwale czy tez } \\
\text { ledwie krótkoterminowe? }\end{array}$ \\
\hline Dopasowarie & $\begin{array}{l}\text { Na ile wybrana opcja pasuje do innych które moga } \\
\text { być zaadoptowane? }\end{array}$ \\
\hline
\end{tabular}

\section{Piśmiennictwo}

1. Biernat K. „Podstawowe problemy analizy i zarządzania ryzykiem dla jednostki i społeczności lokalnej” Materiały Konferencji „Bezpieczeństwo człowieka wobec współczesnych i przyszłych zagrożeń" Drohiczyn, 7-9 września 2004.

2. JAJUGA K. „Zarządzanie ryzykiem” PWN, listopad 2007.

3. KRUP M. „Ryzyko i niepewność w zarządzaniu firmą” PWN, Warszawa, 1999.

4. Buchar R., Grzgorczy K., Hancyk B., „Transport drogowy materiałów niebezpiecznych” Wyd. „IMAGE”, Warszawa 2000.

5. Praca zbiorowa pod redakcją M. Młyńczaka, „Analiza ryzyka w transporcie i przemyśle”, Oficyna Wydawnicza Politechniki Wrocławskiej, Wrocław 1997.

\section{Ecological risk management procedures}

\section{SUMMARY}

Risk management relies on identification, estimation, control and finance of potential risks. Efficient process of management against alternate of ecological threat it's people and nature resources protection before threats related to pollution of water, air, soil and other components of environment, which balance has been broken by reason of pronouncement of unexpected natural phenomenon, industrial failure and human activities. Negative environmental results are caused in case of pronouncement of threat damage to environmental component pollutions and ecosystems changes. 